\title{
Impact of Hypnea pannosa on Lipid Profile
}

\author{
Kanwal Naseer ${ }^{1}$, Rafeeq Alam Khan ${ }^{1 *}$ and Iqbal Azhar ${ }^{2}$ \\ ${ }^{1}$ Department of Pharmacology, Faculty of Pharmacy and Pharmaceutical Sciences, University of Karachi, Karachi 75270 Pakistan \\ ${ }^{2}$ Department of Pharmacognosy, Faculty of Pharmacy and Pharmaceutical Sciences, University of Karachi, Karachi 75270 Pakistan
}

Submission: February 18, 2017; Published: June 20, 2017

*Corresponding author: Rafeeq Alam Khan, Department of Pharmacology, University of Karachi, Pakistan, Email: rkhan1959@gmail.com

\begin{abstract}
Hypnea pannosa is red marine alga, belong to family Hypneaceae [1]. As it as previously investigated that certain marine algaepossess interesting hypocholesterolemic effect. The study of algae is called Phycology and its history is quit old. Hykos is Greek word which means seaweed or algae and is available in Chinese, Roman and Greek literature.This study was undertaken in rabbits to assess the safety profile of an algae H. pannosa. It was tested for the period of 20 days on two groups of rabbits.Each group comprises of seven rabbits of either sex.Biochemical tests were performed at the completion of dosing using standard reagent kit. The result shows that $H$. pannosa revealed significant decrease in triglycerides and HDL ( $\mathrm{p}<0.05)$ and insignificant decrease in LDL in comparison to control animals at completion of dosing.
\end{abstract}

\section{Introduction}

The marine biosphere includes abundance of organism about 500,000 species in 30 phyla. Seaweeds have been used as a source drugs over a long period of time in folk medicine. The earliest particulars on sea weed utilization originate from Chinese materia medica of Shen-nung written in 2700 B.C. The medicinal importance of seaweed is increasing day by day and is expected to play a major role in health of human race, since is known as an excellent source of vitamins and minerals, especially sodium and iodine [2].

H. pannosa belongs to genus Hypnea Family Hypneaceae [3]. It is characterized by a terete to compressed, much branched thallus with short lateral branchlets, globular cystocarps, and zonate tetrasporangia on short laterals [4].

No systemic account on the genus Hypnea is available from Indo Pakistan subcontinent. However, this specie has already been reported for India and Srilanka [5]. The red seaweed, $H$. pannosa, rises as cushions of interwoven filaments adhered to rocks near the lower mark of the marine littoral zone and near Karachi.

Hypnea is easily distinguishable from other species by its characteristic habit of forming low dense matted tufted cushion [6]. This cushion making habit of H. pannosa is unique among the species of Hypnea.

Several species of genus Hypnea have been investigated for a variety of chemical constituents such as fatty acids [7] sterols $[8,9]$, Carbohydrates [10], Protien and carrageenans [11,12], but there are no-account of halogenated derivatives. Six fatty acids had been identified from the extract of $H$. pannosa such as Methyl myristate, Methyl palmitate, Methyl margarate, Methyl oleate, Methyl Stearate. Four sterol and three Brominated sesquiterpenes have been identified from the extract of $H$. pannosa by the mass and H-MNR [13].

H. pannosa showed the presence of cholesterol, 22- dehydro cholesterol and desmosterol [14] H. pannosa showed lethal effect on root knot nematode Meloidogyne javanica [15]. The extract of $H$. pannosa was effective to nematodes and second instar larvae. Therefore, the seaweed might be a potential source for developing ecological significant bioactive compound including biodegradable pesticides and biopharmaceuticals [16].

\section{Material and Methods}

\section{Preparation of extract}

H. pannosa was collected from coastal area of Karachi and dried under shade, the dried algae was crushed and soaked in ethanol for ten days, after which ethanol was evaporated and a dried extract was obtained.

\section{Animals selection}

This study was done on 14 healthy white rabbits of either sex weighing 1000-1500g. All animals were divided in two groups and housed individually in a separate cage, under controlled condition of temperature $\left(22 \pm 2{ }^{\circ} \mathrm{C}\right)$ and humidity (50-60\%). Standard diet and water was provided ad libitum. 


\section{Journal of Complementary Medicine \& Alternative Healthcare}

\section{Dosing}

One group of animals received $50 \mathrm{mg} / \mathrm{kg}$ ethanol extract of $H$. pannosa and served as treated group, while other group served as control and received saline in volume equivalent to respective dose according to their body weight.

\section{Sample collection}

Blood sample of $5 \mathrm{ml}$ were collected from the ear vein twice, first sample after 10 days administration of $H$. pannosa andsecond at the end of dosing period of H. pannosa i.e. 20 days. Blood samples were collected in gel tube to determine lipid profile.

\section{Gross toxicities}

Apparent health of animals was monitored during the experiment period at every one weak interval under the laboratory experiment. Gross toxicities specifically Average weight variation, skin ulceration, loss of interest in food, change in activity, Hematuria, Vomiting and aggressive behavior was observed.

\section{Mortality rate}

Mortality rate of rabbits under investigation was observed during the total period of experimentation.

\section{Lipid profile}

Serum were instantly separated out by centrifuging blood sample at 4000rpm for about 15 minutes and Cholesterol, triglycerides, HDL and LDL was analyzed within 3 hours on Humalyzer 3000, a semi-automatic chemistry analyzer, Model Number 16700 (Human Germany) using standard kits supplied by Human.

\section{Statistical Analysis}

All values expressed as mean and standard error to the mean (SEM) analyzed using student test. Results with $P$ value less than 0.05 were considered significant and highly significant with $P$ value less than 0.005 .All the statistical procedures were performed according to the method of Alcaraz \& Jimenez [17].

Results

\section{Gross toxicity}

No gross toxicity was observed in any animal group during the total period of experimentation.

\section{Mortality rate}

There was no death in any animal group.

\section{Lipid profile}

Table $1 \& 2$ shows results of $H$. pannosa $50 \mathrm{mg} / \mathrm{kg}$ on lipid profile after 10 and 20 days administration. Data analysis of blood samples in animals fed with $H$. pannosa indicated that dietary consumption of $H$. pannosa decreased total cholesterol, HDL and Triglycerides but effect on LDL was similar to control.
Table $1 \& 2$ shows the comparison of cholesterol, triglycerides, HDL and LDL levels after 10 and 20 days administration of $H$. pannosa in the dose of $50 \mathrm{mg} / \mathrm{kg}$

Table 1: Effect of H. Pannosa on Lipid Profile after 10 Days.

\begin{tabular}{|c|c|c|}
\hline \multirow{2}{*}{ Parameters } & \multicolumn{2}{|c|}{ Animal Groups } \\
\cline { 2 - 3 } & Control & H. pannosa \\
\hline Cholesterol (mg/dl) & $298.1 \pm 18$ & $120 \pm 19^{* *}$ \\
\hline Triglyceride (mg/dl) & $238.1 \pm 6.9$ & $91.1 \pm 16^{* *}$ \\
\hline HDL (mg/dl) & $28.3 \pm 1.8$ & $20.1 \pm 2.2^{*}$ \\
\hline LDL (mg/dl) & $81.3 \pm 1.2$ & $83.6 \pm 0.84$ \\
\hline
\end{tabular}

$\mathrm{n}=07$; Average values \pm S.E.M; ${ }^{*} \mathrm{p}<0.05$ as compared to control; ${ }^{* *} \mathrm{p}<$ 0.005 as compared to control.

Table 2: Effect of H.Pannosaon Lipid Profile after 20 Days.

\begin{tabular}{|c|c|c|}
\hline \multirow{2}{*}{ Parameters } & \multicolumn{2}{|c|}{ Animal Groups } \\
\cline { 2 - 3 } & Control & H. pannosa \\
\hline Cholesterol (mg/dl) & $256.1 \pm 14$ & $112.4 \pm 19^{* *}$ \\
\hline Triglyceride (mg/dl) & $229.1 \pm 7.3$ & $82.6 \pm 13^{* *}$ \\
\hline HDL (mg/dl) & $26.86 \pm 2.0$ & $16.57 \pm 1.3^{* *}$ \\
\hline LDL (mg/dl) & $80 \pm 1.5$ & $81.71 \pm 0.75$ \\
\hline
\end{tabular}

$\mathrm{n}=07$; Average values \pm S.E.M; ${ }^{* *} \mathrm{p}<0.005$ as compared to control.

Animals showed highly significant decrease in cholesteroli.e. $120 \pm 19$ and $112.4 \pm 19 \mathrm{mg} / \mathrm{dl}$ in comparison to control animals i.e. $298.1 \pm 18$ and $256.1 \pm 14 \mathrm{mg} / \mathrm{dl}$ respectively after 10 and 20 days administration of $H$. pannosa, while there was also highly significant decrease in triglycerides i.e. $91.1 \pm 16$ and $82.6 \pm 13 \mathrm{mg} /$ dl after 10 and 20 days administration of $H$. pannosa in comparison to control animals i.e. $238.1 \pm 6.9$ and $229.1 \pm 7.3 \mathrm{mg} /$ $\mathrm{dl}$ respectively. However decrease in HDL was significant after 10 days and highly significant after 20 days in comparison to control animals. The change in LDL levels was almost comparable to results of control animal.

\section{Discussion}

The marine biosphere includes abundance of organisms about 500,000 species in 30 phyla. Seaweeds have been used as a source drugs over a long period of time in folk medicine. In China and Japan seaweeds have been used as medicine from the early days. The medicinal importance of seaweed is increasing day by day and is expected to play a major role in health of human race.

The cost of Karachi is inhabited by a variety of marine algae which are yet to be explored. This work has therefore initiated to realize the bio activity and medicinal significance of certain seaweeds from the cost of Pakistan. In spite of all the limitation of facilities and poor availability of existing technology the marine environment positively deserves continual exploration as a source of new drug which may be of considerable valuable in the socio economic growth of nation.

The present work is design to study the hypolipidemic activity of marine algae, Hypneapannosa family Hypneaceae, as 


\section{Journal of Complementary Medicine \& Alternative Healthcare}

it was previously investigated that certain marine algae possess interesting hypocholesterolemic effect $[18,19]$ shows highly significant decrease in cholesterol, Triglycerides and significant decrease in the level of HDL on 10 days while on 20 day highly significant decrease in the level of HDL is found The daily addition of sea products such as sea weed and fish oil to diet has been suggested for prophylaxis of coronary atherosclerosis [20]. Russian scientists have used marine products and marine algae for lowering the cholesterol level in blood plasma.

Several species of genus Hypnea have been investigated for a variety of chemical constituents such as sterols, protein, carrageenans and polysaccharides. Sterols and polysaccharides have been reported to produce hypolipidemic activity [21] hence hypocholesterolemic activity of hypnea may be due presence of sterols and polysaccharides in marine algae [22]. Red seaweed species containing nontoxic sterols have reported reduce blood cholesterol level and retard the accumulation of fats in liver and heart. Polysaccharides from the red and brown algae have also shown the hypolipidemic activity [23,24]. Carrageenan is the mixture of polysaccharides obtained from the various red sea weeds. Afaq et al. [13] the Hypocholesterolemic and hypolipidemic activity of Carrageenan has been also. However it is suggested that more elaborated studies are required to reach at definite conclusion.

\section{References}

1. Valeem EE, Shameel M (2012) An account of fatty acid composition of algae growing in Pakistan. Int J Phycol Phycochem 8(2): 115-126.

2. Kolanjinathan K, Ganesh P, Saranraj P (2014) Pharmacological importance of seaweeds: A review. World Journal of Fish and Marine Sciences 6(1): 1-15.

3. Silva PC, Basson PW, Moe RL (1996) Catalogue of the Benthic Marine Algae of the Indian Ocean. University of California Press, USA.

4. Geraldino PJ, Riosmena-Rodriguez R, Liao LM, Boo SM (2010) Phylogenetic relationships within the genus hypnea (gigartinales, rhodophyta), with a description of Caespitosa. NOV J Phycol 46: 336345 .

5. Borgesen F (1937) Contributions to South Indian marine algal flora-II. J Ind Bot Soc 16: 311-357.

6. Okamura K (1921) Icones of Japanese algae. 4(5): 85-107.

7. Hayee-Memon A, Shameel M, Usmanghani K, Ahmad VU (1992) Fatty acid composition of three species of Hypnea (gigartinales, rhodophyta) from Karachi coast. Pakistan Journal of Marine Sciences 1(1): 7-10.
8. Tsuda K, Sakai K, Tanabe K, Kishida Y (1960) Steroid studies. XVI Isolation of 22-dehydrocholesterol from Hypnea japonica. J Am Chem Soc 82(6): 1442-1443.

9. Fattorusso E, Magno S, Santacroce C, Sica D, Impellizzeri G, et al. (1975) Constituents of red algae. II. Sterols of some red algae. Phytochem 14: 1479-1582.

10. Mahran GH, Soliman FM, Fathi MM (1985) Carbohydrates of Hypnea musciformis (Wulf). Lamx Egypt J Phar Sci 24: 131-137.

11. Rao KR, Krishnamurthy V (1978) Studies on Indian Hypneaceae I Seasonal variation in phycocolloidcontenting two species of Hypnea (Gigartinales, Rhodophyceae). Bot Mar 21: 257-259.

12. Combaut G, Kornprobst JM, Mollion J (1981) Chemistry of seaweeds from Senegal. Int Conf Chem. Biotech Biol Act Nat Prod 3: 272-276.

13. Afaq-Husain S, Shameel M, Usmanghani K, Ahmad M, Perveen S, et al (1991) Brominated sesquiterpene metabolites of Hypnea pannosa (Gigartinales, Rhodophyta). Journal of Appl Phycol 3(2): 111-113.

14. Hayee-Memon A, Shameel M, Usmanghani K, Ahmad M, Khan $\mathrm{R}$, et al. (1991) Phytochemical studies on Scinaia fascicularis (Bonnemaisoniales, Rhodophyta). Pakistan Journal of Pharmaceutical Science 4(3): 27-34.

15. Sasser JN (1980) Root-knot nematodes: a global menace to crop production. Plant Disease 64(1): 36-41.

16. Manilal A, Sujith S, Kiran GS, Selvin J, Shakir C, et al. (2009) Biopotentials of Sea weeds Collected from Southwest Coast of India. Journal of Marine Science and Technology 17(1): 67-73.

17. Alcaraz MJ, Jimenez MJ (1989) Anti-inflammatory compound from sideritis javalambrensis n-hexane extract. J Nat Prod 52(5): 1088-1091.

18. Kaneda T, Tokuda S, Arai K (1963) Studies on theeffects of marine products on cholesterol metabolism,the effects of edible seaweed. Bulletin Jap Soc Sci Fish 29(11): 1020-1035.

19. Jehan Ara, Sultana V, QasimR, Ahmad VU (2002) Hypolipidemic activity of seaweed from Karachi coast. Phytother Res 16(5): 479-483.

20. Chunacova EP (1967) Change in the permeability of blood capillaries in patients with coronary atherosclerosis under the effect of an antisclerotic diet. Sov Med 30: 30-35.

21. Tsuchiya Y (1969) Comparative hypocholesterolemic activities of marine algae. Proceeding of the International Seaweed Symposium 6: 747-757.

22. Wong KH, Sam SW, Cheung PCK, Ang PO (1999) Changes in lipid profiles of rats fed with seaweed-based diets. Nutrition Research 19(10): 15191527.

23. Bhakuni DS, Silva M (1974) Biodynamic substances from marine flora. Botanica Marina17(1): 40-51.

24. Studies on lipid of marine algae: Sterol and fatty acid composition of marine algae. kyoyobu kenkyu hokoku (gofu daigaku)18: 53.
Your next submission with Juniper Publishers will reach you the below assets

- Quality Editorial service

- Swift Peer Review

- Reprints availability

- E-prints Service

- Manuscript Podcast for convenient understanding

- Global attainment for your research

- Manuscript accessibility in different formats

( Pdf, E-pub, Full Text, Audio)

- Unceasing customer service

Track the below URL for one-step submission https://juniperpublishers.com/online-submission.php 